\title{
Global Söylemin Hakim Gücüne Karşı Bir Ses Olarak İsmet Özel'in Millet Söylemi
}

\section{The Discourse of İsmet Özel on the Nation against the Global Discourse of the Dominant Power}

\begin{abstract}
Arif AYTEKIN**
Öz: Söylem, dünyaya hükmetme düşüncesinin merkezi yerini işkâl etmektedir. Batı, uzun yıllardır söylem gücünü elinde tutmaktadır. Batının keşif kolu, öncü birlikleri artık söylem üzerine odaklanmaktadırlar. Daha önce topraklara, stratejik noktalara, üsleri kuşatmaya yönelen Batının tahkim gücü artık zihinlere, toplumun hafızasına, kültürel kodlarına hâkim olmaya yönelmektedir. Batının, bilgi, iktidar, güç ilişkisinde hâkim olduğu düzene muhalif veya alternatif olabilecek muhtemel imkânları ortadan kaldırmak, onları "dumura" uğratmada öncelikli işlevsel gücü söylemdir. Artık söylem, dünyayı anlamaya açılan bir kapı olmaktan çıkmış ona hükmetmenin imkânı, başat aracı olmuştur. Bugün batı medeniyeti olarak taçlanan güç temerküzü esasta Türk/İslam karşıtı ve Türklerle/Müslümanlarla başetmek için oluşmuş/ oluşturulmuş bir yapıyı temsil etmektedir. Türk milleti, Batı Hristiyan topluluklarla girdiği mücadele süresince üstlendiği tarihi bir rol sonucu oluşmuştur. Aynı tarihi diyalektik çatışmanın karşıt kutbunda ise bu günkü Avrupa düşüncesi ve kurumları doğmuştur. Bu önermelerle İsmet Özel, bir taraftan Batı'yı dayandığı fikri temelleri ile izah ederken, öbür taraftan ise Türklerin/müslümanların bu topraklarda tutunabilmelerinin esas sebebinin bir "millet" hayatının varlığına bağlayarak düşüncelerini açıklamaktadır. Bu sebeple Özel, millet mefküresini kaybetmiş bir Türkiye'nin geleceğinin muhal olduğunu imlemektedir.
\end{abstract}

Anahtar sözcükler: İsmet Özel, İslam, Söylem, Millet, Türk, Dünya Sistemi

\begin{abstract}
Control over discourse is the main point in invading the world. The west has been in control of the power of discourse for years. The vanguard in the west has been focusing upon control over the discourse. The west with a tendency in the past to besiege lands, strategic locations, and bases, has now diverging to dominate minds, the public memory, and cultural codes. Discourse is the only functional power able to eliminate knowledge, power and the domination by their world, or the alternative possibilities in defeating them. Discourse is not only a tool to understand the world, but also the primary element of rule. Today, western civilization which is a concentration of power is basically a representation of the structure against Turkish/Islam. Turkish society has been formed as a result of the battle against West/Christian societies. On the other side of this historical dialectic, current European ideas and institutions have been formed. With these propositions İsmet Özel has been explaining the west through his ideas, on the other hand, he states that the concept of "nation" is the ultimate reason which enables Turks/Muslims to strive in this land. For this reason Özel implies that the future of a Turkey which loses its ideology of a nation is not possible.
\end{abstract}

Keywords: İsmet Özel, Islam, Discourse, Nation, Turkish, Global System

\footnotetext{
*Yrd. Doç. Dr., Akdeniz Üniversitesi, Manavgat MYO, Antalya. arifaytekin@ akdeniz.edu.tr, plihoa1 @ gmail.com
} 


\section{Giriş}

Söylem ve kimlik arasındaki hayati ilişki, toplumsal ve siyasal bütünleşmenin (consensus) merkezi yerini teşkil etmektedir. Her ne kadar Türkiye'de "biz kimiz? Nereye aidiz?" sorusuna verilen cevap bir dönem toplumsal kimliğin çatısını oluşturmada sarih idise de, modern/küresel dönemde bilgi-iktidar ilişkisinde kaynakların çeşitlenmesiyle bu çatının kurulması büsbütün zorlaşmakta ve müphem bir hal almaktadır. Milletlerin hayali, "ideal toplum" anlayışlarının gövdeleşmesi ile oluşan ulus-devletlerin, yukarıdan uluslararası örgütler ve aşağıdan mikro milliyetçilikler aracılığı ile sıkıştırıldığı günümüzün küresel dünyasının estirdiği kasırgalar, önce toplumsal aidiyetin/kimliğin, sonra da ulus-devletlerin çatısını birer birer uçurmaktadır (Anderson 2009). Bu durum, sadece teorik bir aksiyomdan ibaret olmayıp aynı zamanda, Türkiye'nin komşusu birçok ulus-devlette sonuçlanmış, sıkıntıları Türkiye'nin her tarafından hissedilir bir aşamaya geçmiştir. Türkiye Cumhuriyeti, kuruluşundan itibaren dünya sistemi yörüngesinde uyguladığı seküler politikaların neticesi olarak bugün bazı sorunlar ile karşı karşıyadır. İsmet Özel'in iddiasına göre, eğer günümüzde Türkiye, Cumhuriyet yönetiminin açtığı kanalda yürümeye devam ederse, Türk ile Müslümanlık arasındaki bağların koparılmasına yönelik politikalarda ısrar ederse, yani İstiklal Marşı'nın hedef gösterdiği ideolojiyi rafa kaldırırsa, bugün sahip olduğumuz "dertler" yarın başımıza "belaya" dönüşür (Özel 2010b, $325)$.

Her millet ürettiği söylemle kendisini kurgular/oluşturur. Anderson'un "ulusu hayal edilmiş bir siyasal topluluk olarak tanımlaması" bu yargiya kuvvet vermektedir (Anderson 2009, 20). Söylem, M. Foucault ve Edward Said'in vurgulaması ile daha çok Batı'nın, Şarkı aşağı düzeyde gösterip üretmek suretiyle, Batı'nın tahakkümünü/hegemonyasını garantileyen bir iktidar/bilgi biçimi olarak öne çıkmıştır (Rattansi \& Westwood 1997, 52). Söylem, aynı zamanda milletin dayandığı temel kodlarla diyalojik ilişki içindedir (Gellner 2006, 32). Millet ve söylem karşılıklı bağımlılık ilişkisiyle birbirlerini beslemektedirler. Bir milletin ürettiği söylem, yani dünyayı anlama, kendini anlamlandırma ve konumlandırma çabası, aynı zamanda o milletin yeniden biçim almasında belirleyici rol oynamaktadırlar. Ulus-devletlerin inşa sürecinde yapılan tarih yazımlarında, ulusun geleceğinin kurgulanması, büyük ölçüde geçmişin inşaası için üretilen söyleme dayanmaktadır. Söylemin inşa edici özelliği ile millet, gelecek hedefleri doğrultusunda, dayandığ temelleri ile yeniden kodlanarak tarihi bir role bürünür. Bu çerçevede 1931 yılında Türk Tarih Cemiyeti'nin kurulması, ardından 1932'de Türk Tarih Kongresi'nin toplanması ve sonrasında oluşturulan literatürün büyük ölçüde İslam öncesi Türk üzerine kurgulanması, Orta Asya'nın asıl Türk vatanı olarak benimsenmesi, Güneş Dil Teorisi'nin yanında filolojik ve belli bir tarih görüşü doğrultusunda "saf" Türk oluşturma gibi çalışmalar öne çıkmaktadır (Mardin 2012, 290).

Sosyal bilimlerde birçok kavram gibi "millet" kavramı da üzerinde uzlaşılmış kesin bir anlamdan yoksundur. Bilim adamlarının fikri arka planına ve önceliklerine göre, millet kavramı farklı anlamlarla anılmaktadır. Milli kimlik olarak "milleti" modern anlamda etniklik ile açıklayanların olduğu gibi milleti; oluşturulmuş soyut, ideal bir kavram olarak yorumlayanlar da mevcuttur. Her ne kadar tarihsel bakımdan ilk milletler modern öncesi etnik çekirdekler temalinde oluşmuştur yargısı hâkim olsa da, örgütlü dinlerin siyasal organizasyon ve askeri güç bakımından merkezi konuma gelmelerinden sonra "millet" kavramının asıl gövdeye ulaştığı ileri sürülebilir. Her iki durumda milli kimliğin temelinde olan millet kavramı soyut ve karmaşık bir doğaya sahiptir (Hobsbawm 2006, 19). Bu sebeple millet kavramının oluşturucu öğeleri, tarihi bir toprağı/ülkeyi, ortak mitleri ve tarihi belleği, kitlevi bir kamu kültürü, ortak/milli bir ekonomi, ortak yasal hak ve görevleri paylaşan insan topluluğu gibi kriterlerle, onları diğerlerin- 
den farklı kılan özellikler sayılabilir (Smith 2010, 31-32).

Ernest Gellner'in deyişi ile "ulusçuluk" ulusların bir ürünü değildir, tam tersine, ulusları meydana çıkaran ulusçuluğun kendisidir (Gellner 2006, 138). Milletlerin görünürlük kazanması görece modern döneme ait bir olgu olarak görülse de onları oluşturan sosyal, dini, kültürel, genetik kodlar, toplumsal yaşamın tarihi kadar eskidir. Bu bakımdan din, bilinen ilk toplum yaşamından itibaren etkinliğini bütün boyutları ile toplumsal yaşamda hissettiren bir öğe olarak milletin biçim kazanmasında belirleyici bir özelliğe sahip olmuştur. Bir bakıma millet kavramı Fransız İhtilaline kadar bütün dünya literatüründe din ile eşanlamda kullanıla gelmiştir. Fransız İhtilalinden sonra bugün kullandığımız anlamda 'nation' terimi dinden arındırılmış, seküler bir içeriğe büründürülmüştür. Bu sebeple din, ilk toplumlardan modern yaşama kadar toplumsal kültürün oluşmasında doğrudan, milletlerin karakter özelliklerinin biçim almasında dolaylı olarak inşa edici bir rol almıştır. Bir milletin özgün kimliğini kazanmasında etkili olan; şiir, edebiyat, sanat, ahlak, değer yargıları gibi toplumsal ögelerin hemen hemen hepsinde dinin kalıcı etkisinden söz edilebilir. Türk milletinin karakter kazanmasında, aldığı tarihi görev/rolde büyük ölçüde İslam dini ile tanıştıktan sonra, Selçuklu-Osmanlı döneminde biçim aldığı ileri sürülebilir. Türk milletinin batı dünyasında, edebiyatında kazandığı anlamda bu durum daha net anlaşılmaktadır. Bir etnisite terimi olarak "Türk" kelimesi Batı literatüründe "Íslam" ile eşanlamda kullanılmaktadır. Müslüman Türk terimini kullanma gereği neredeyse yoktur, çünkü Türk zaten Müslüman olarak kabul edilmektedir. Özel'in konuşmalarında ve yazılarında sıkça vurguladığı İslam ile Türklük arasındaki özdeşlik ilişkisini B. Lewis'de dikkat çekmektedir. Lewis, Hıristiyan Araplardan söz edilebileceğini, Hıristiyan Türk tabirinin saçma bir ifade olduğunu, batılı bir zihnin kabullenemeyeceği bir durum olduğunu ifade etmektedir (Lewis 2000, 15). İslam ile Türklük arasında oluşan bütünlük/eşanlamlılık zamanla da anlam genişlemesine uğrayarak bütün Türk kavimlerini, Balkanlarda ve Anadoluda birçok etnisiteyi kuşatır hale gelerek genel bir karakteristiğin ifadesine dönüşmüştür (Günay 2000, 519).

İsmet Özel, bu bağlamda Türklüğü, Türk milletinin ayırt edici vasfı olarak "cihadı şarta bağlamama" olarak öne sürmektedir (Özel 2013, 92). Benzer bir iddiayı filozof Teoman Duralı da, Türk milletinin biçimlenmesinde İslam dini vardır. "İslam medeniyetinin belirgin özellikleri tanınmadan Türklük anlaşılmaz" düşüncesini ileri sürmektedir (Duralı 2013). Türklügün Batı literatüründe Özel'in kullandığı anlamda anlaşıldığına dair birçok örnek literatüre geçmiştir. "The Mahumetane or Turkish Historie" bu ifade de "orlveya" bağlac1, Türklük ve Muhammedîlik kavramlarının eş düzlemde görüldüğü açıktır. Müslüman ile Türkün özdeşliğine dair bir diğer önemli ifade, "The Author of the Turkish Religion/Türk Dininin Müellifi" ifadesidir. Bunun yanında Bernard Lewis'in, tespitine göre, Osmanlı Türkleri kendilerini İslamlıkla özdeş görmüşler, başka uluslardan daha çok kendilerini İslamlık içinde eritmişlerdir. Türk sözcügü Türkiye'de hemen hemen hiç kullanılmaz iken, Batıda Müslümanlık ile eş anlamda kullanılmakta idi. Müslüman olmuş bir batılıya, olay İsfahan'da veya Fas'ta olsa bile, "Türk olmuş" denmesi ilginç olmanın yanında, Özel'in dikkat çektiği bu durumu net bir şekilde açıklığa kavuşturmaktadır (Lewis 2000, 13). Öte yandan Anadolu topraklarına "Turchia" isminin Türklerle savaşan Haçlı komutanı Barbarossa tarıfından verildiği de kayıtlarda mevcuttur (Bozkurt 2016, 43). "Turchia" ismi, İsmet Özel'in “Türk" (kâfirle savaşmayı göze alan Müslüman) kelimesinden mülhem olarak "Íslam beldesi" anlamında verildiği düşünülmektedir. Bilindiği gibi "kimlik" temelde bir kültür sorunudur, büyük ölçüde kültüre bağlı, kültür içinde biçim alır (Güvenç 2016, 5). Bu sebeple "Türk", "Türklük" ve "Türkçe" gibi değerler İslam kültürü içinde biçim almış, temayüz etmiş kavramlar olarak öne çıkmaktadır.

Birçok milletin oluşumunda dinin rolü yadsınamaz. Din ile milli oluşumlar iç içe geçmiştir. 
Çoğu yerde dini olan ile milli olan ayırt edilemez bir hal almıştır. Bu bakımdan din, milli kimliğin oluşmasında ve aynı kimliğin korunmasında çok önemli bir işleve sahiptir. Batı literatüründe Türk milletinin belirgin özelliği vurgulandığında ontolojik, antropolojik ayırımlardan çok din ile milletin özdeşleşmesinden doğan tarihi rol öne çıkmaktadır. Türklerin tarihte aldığı görev, üstlendiği rol ümmeti Muhammedin mesuliyeti olarak belirginlik kazanmaktadır. Bu rol sadece Batının fark ettiği bir durum değil, aynı zamanda Güney Doğu Asya'da ve birçok yerde hissedilen bir durumdur. Singapur Müftüsünün, "Türk bayrağı altında olmadığımızdan cuma namazını eda edemiyoruz" deyişi bu çerçevede değerlendirilebilir (Özel 2015, 95).

Milletlerin oluşumunda, etno-millet, etno-dinsel, kulturnation (kültürel-millet), staatsnation (devlet-millet), teritoryal millet, tarihi toprak - "Fışkırır ruh-i mücerred gibi yerden na'şım, dizesinde temayüz eden anlam" - patria (vatan) gibi kavramların etkileşimiyle millet; tarihi bir toprağ1/ülkeyi, ortak mitleri ve tarihi belleği, kitlevi bir kamu kültürünü, ortak bir ekonomiyi, ortak yasal hak ve görevleri paylaşan insanların oluşturduğu bütünsel bir yapının süreklilik arz etmesi olarak nitelenebilir (Smith 2010, 114). Smith'in milleti oluşturan unsurlarını dikkate aldığımızda, Türk milletinin oluşumunda etno-millet (biyolojik köken) özelliği silik tutmak kaydıyla, diğer bütün unsurları belirgin bir biçimde ilkin Anadolu topraklarında 12. yüzyıldan itibaren oluşmaya başladığını ve İstiklal Savaşı ile ikinci kez vatanlaşması suretiyle, bu toprakların Türk milleti ile örtüşmesinin kesinlik kazandığını ileri sürülebiliriz. Benzer bir bakış açısını Albert Sorel gibi Fransız düşünürlerin tezlerini temel alan Yahya Kemalde de görmek mümkündür. "Malazgirt'ten sonra Türkiye toprağında yalnız kendine benzeyen bir Türklük vardır. Bu Türklük, kendi ırkından, bağgl olduğu dinden, yaptığı tarihten yarattığ güzel sanatlardan, şïrden, musikiden, duyuşundan, kendi kaza ve kaderinden terekküp etmiş (oluşmuş) bir kitledir" (Kabaklı 2017, 114). Görüldüğü gibi Yahya Kemal de milletin birliği konusunda ortak tarih, Anadolu coğrafyası ve İslam dini gibi temel sabiteleri esas almaktadır. Bir dizesinde çok çarpıcı bir ifade ile 1071 Malazgirt öncesini "Tarih öncesi” gibi algıladığını ifade etmektedir (Kabaklı 2017, 123). Bu tezin söylem düzlemi farklılaşmış ve İslam vurgusu artırılmış bir biçimde 21. yüzyılda şair İsmet Özel tarafından daha kuvvetli bir biçimde savunulmaktadır.

Türk milleti kavramının oluşumunda İslami kültürün dozu asırlarca hep ağırlıklı unsur olarak olagelmiştir. Ancak kapitalist dünya sistemin hegemonyasının artmasına koşut, tarihsel olarak Birinci Dünya Savaşı'ndan sonra İstiklal Harbi'nin başarıyla verilmesi neticesinde Türkiye Cumhuriyeti Devleti'nin bir İslam Devleti olarak kurulmasına ve "İstiklal Marşının" açık ideolojik hedeflerine rağmen, yeni kurulan cumhuriyetin ulus-inşa etme politikalarında asırlarca ağırlıklı unsur olan islam kültürünün itina ile temizlenmesi, silinmesi yönünde politikalar uygulanmıştır. H. Bülent Kahraman, yeni kurulan cumhuriyet yöneticilerinin kültür alanında, modernist, pozitivist ve laisist tercihlerle İslami geçmişe yönelik ciddi bir "inkârcıllı̆̆ ve reddiyeyi" hiç çekinmeden denediklerini ve onu silme yönünde politikalar uyguladıklarını ileri sürmektedir (Kahraman 1999). Bir bakıma Cumhuriyet dönemi yöneticileri, kendi söylemlerini temellendirmek için Osmanlı-Selçuklu kültür bakiyesini, daha doğrusu İslam dini ile bağlantılı geçmişe dair ne varsa hepsini, Cemil Koçak'ın ifadesiyle "itina ile temizleme" yoluna gitmiştir (Koçak 2010). İslam'dan koparılmış Türkü veya Türkiye'yi tasvir ederken Ahmet Kabaklı "Bizi kökümüzden koparıp kuru kütükler gibi yol kenarına koydular" ifadesi ile dikkat çekmektedir (Kabaklı 2006, 22). Neredeyse Cumhuriyet dönemi elitleri, sömürgeden yeni kurtulmuş bir siyasal yapının kendisini sömürenlere karşı aldığı garda benzer bir tutumu, İslam kültürüne karşı almıştır. Bu pozisyon alışa 1950'lerde çok partili hayata geçildikten sonra Peyami Safa çok sert bir üslupla, Cumhuriyet yönetimini "dinsizler, kitapsızlar, inançsızlar, 
Allahsızlar" diye eleştirmiştir (akt. Güvenç 2006, 54). Bu çalışmada, Cumhuriyet dönemi elitlerinin İslam'a karşı böylesine yok edici, silici bir pozisyon almasında, dünya sisteminin etkisinin olup olmadığ yönünde İsmet Özel'in metinlerinden iz sürüleceği gibi; Türk milletini İslam kültüründen soyutladığımızda veyahut Türk milletinden İslam'ı çekip aldığımızda geriye Türkün kalıp kalmayacağı meselesinde Özel'in aidiyet konusundaki düşünceleri detaylı olarak tartışılacaktır.

Hegemonya hem anlamlandırır hem de yapılandırır. İyi işleyen bir hegemonya kendi öznelerini yapılandırır/yaratır (Rattansi \& Westswood 1997, 327). Tanzimatla başlayan ve Cumhuriyetle artarak devam eden İslam'dan arındırılmış "Türk" oluşturma yönündeki kültür politikalarını, dünya sistemi çerçevesinde belli bir hegemonyanın inşa faaliyeti olarak değerlendirmek mümkündür. İsmet Özel, önceki bütün milliyetçi görüşlerden farklı olarak, Türk milleti kavramının oluşumunda İslam dışı bir kimliğin varlığından söz edilemeyeceğini 1srarla ileri sürmektedir (Özel 2012, 15). Dahası Özel, Türkiye'de İslam ile Türklük arasında mesafe açmaya yönelik çaba sarf edenleri ya da ufkunda Müslüman bir Türkiye olmayanları, bunlara "pasta peşinden koşan Siyasal İslamcılar ve ısmarlama Müslümanlar" da eklenebilir, bunların hepsini dünya sisteminin yörüngesinde işlerle meşgul olan millet düşmanları olarak nitelemektedir (Özel 2012, 165). Bir bakıma Özel, gerek 12. yüzy1lda, gerek İstiklal Harbinde ve gerekse gelecekte, mevcudiyetini Kur'anı Kerim'in nüzulüne borçlu olmayan bir Türkün, Türk topraklarında geleceği yoktu/yoktur (Özel 2013, 73). İddiasını yüksek bir sesle vurgulamaktadır. Daha açık bir ifade ile Özel, "Müslüman vasfimız bünyemizden alındı̆̆ takdirde ne topraklarımız kalır, ne de devletimiz" iddiasını ileri sürmektedir (Özel 2010b, 358).

\section{İsmet Özel'de Türk Kavramı}

İsmet Özel 1960'lardan günümüze değin gerek şair olarak ve gerekse düşünceleri itibari ile Türkiye'de hem sol, hem sağ ve hem de İslamcı entellektüel çevrelerin ilgisini, tepkisini çekmiş, göz ardı edilmesi mümkün olmayan ve popülist söyleme bulaşmayan ender düşünürlerden biridir. Özel'in, Türkiye'nin bağımsız bir ülke olması için verdiği fikri mücadele, Onu 1960'l1 yıllarda sosyalist düşünceye, 1970'li yıllarda aynı düşünce Onu İslamcıllk fikrine, 2000'li yıllarda ise "Türk, Türk Milleti, Biz Türkler" gibi kavramlarla temayüz eden kimlik/aidiyet düşüncesine yaklaşarak nöbet yerini belli etmiştir (Aytekin 2014). Dışarıdan bakanların aksine Özel, nöbet yerinin değişmesine dair, "hangi sebeplerle sosyalist olduysam, aynı sebeplerle Müslüman oldum" ifadesini kullanmaktadır (Özel 2010c, 53). Entelektüel dünyada küreselleşme tartışmalarının hız kazanması, ulus-devletlerin küresel şirketler ile mikro milliyetçilikler arasında sıkışması, ulus-devletlerin miadını doldurduğu gibi tezlerin küre üzerinde yaygınlaşması milletler aleyhine çokuluslu şirketlerin lehine olan bir süreci, yani milletlerin tamamen dünya sisteminin yörüngesine girdiği, muallâkta durduğu ve zamanla yok olma tehlikesi ile karşı karşıya kaldığı bir dönemde, Özel kendisine nöbet yeri olarak millet, milletleşme istikameti, aidiyet meselesini seçmiştir (Özel 2010b, 7). Onun bu seçimi, zihinleri kuşatma altında tutan küresel hegemonyaya karşı bir tepki ve Türkiye'nin muallâkta/kararsız bulunma haline bir çıkış yolu olması bakımından önemsenmektedir.

Özel, Tanzimat'tan bu yana fiili olarak dünya sistemi yörüngesinde politikaların uygulanma olanı olarak yönetilen Türk milletinin bağımsız bir ülkeye kavuşması için 1960'lı yıllarda sosyalist düşünce, 1970'li yıllarda ise İslami düşüncenin bir çıkış yolunu bulması bakımından fırsat/imkân sunduğunu, fakat her iki imkânın da kendi temsilcileri tarafindan heba edildiğini ileri sürmektedir. 21. yüzyıla gelindiğinde Türkiye eş zamanlı olarak iki olgu ile karşı karşıya kalmıştır: Birincisi, dünya sistemi yörüngesinde, onun talepleri doğrultusunda pazarlık gücüyle elde edilecek firsatlara, işaret etmektedir. "İkinci olgu, Türkiye’nin kimliğine sahip çıkma 
yolundaki çabalarından, bir müflis kılı̆̆ altında kalmak mecburiyetinde bırakılarak vazgeçmiş bulunmasıdır". Bu ikinci olgunun Türkiye için dünya sisteminin gücü karşısında doğal olarak kendi kimliğinden vazgeçmeye icbar edilmesi olarak düşünülebilir. Bu bakımdan gerek boyun eğiş ve gerekse gönüllü modernleştirme politikaları şeklinde olsun, Türkün benliğine dair karakter ve şahsiyet inşa etmede, Tanzimattan bu yana yöneticiler, milletin önüne hedef koyma bakımından yetersiz kalmıştır. Artık günümüzde çevremizdeki milletlerle aramızdaki mesafe silikleşme yoluna girmiş̦ir. "Türk isek sıradan bir Balkanlıdan seni-beni ayıran nedir? Türk isek sıradan bir Orta-Doğuludan seni-beni ayıran nedir?" gibi sorularla Özel, kapitalizmin milletler üzerinde sağladığı kültürel boyun eğişle, millet mensuplarını otantik değerlerinden soyutlayarak, onları tüketip, tükenen ve sıradan, benzer nesnelere dönüştürmüştür, önermelerini ileri sürmektedir (Özel, Kasım 2002).

Özel, Türk milletini tanımlamada kullandığı önermelerden biri de "Kapitalizme direnen bu millete ben Türk diyorum" şeklindedir (Özel 2010c, 12). Bu bakımdan, "Bir adı da kapitalizm olan dünya sistemini özüyle ve biçimiyle reddederek Türkiye'nin kurtuluşuna açılan bir yola girmek ülkemizde ipleri ellerinde bulunduran çevrelerin son kırk yllda yönetim felsefesi itibariyle sosyalizmi veya İslâmiyet'i benimsemesiyle mümkün olabilirdi, olmadl. Kimlik konusunda Türk milletinin ayağı sürçtükçe siyasi kadrolarındaki laçkalaşma tahammül edilmez bir hal alıyor. Laçka siyasi kadrolar gemi azlya alıp kimlik arayışları dolayısıyla doğan bütün meseleleri çözümsüzlüğe sürüklüyor" (Özel, Kasım 2002). Bu sebeple Türk kültür hayat1, bütün toplum etkinliklerini kapsayan biçimde, bireylerin temel insani zaafları hesaba katılarak kapitalizmin tüketim önerileriyle felç edilmiştir. Özel, Türk kültür hayatının bu denli felç edilmesinin veya onun tabiri ile "pisliğe bulaşmasının" başat sebebi olarak kapitalizm veya dünya sistemi denilen ve Tarihsel olarak Türk varlığına tepki olarak oluşmuş düzene karş1 koyamayış1 veya ondan medet umar duruma düşmesi olarak görmektedir. Kurtuluş ve diriliş mümkünse bu ancak tekrar kendimize gelmekle, Kim olduğumuzu, nereden geldiğimizi bilmekle mümkün olur. Özel'in daha önce farklı bir bağlamda yazdığı metinde geçen alegorik dize, bu durumu açıklamada çağrışım zenginliği yaratmaktadır. "Biz devemizi kaybettik, kaybolan devemizin üzerinde biz vardık, biz kendimize gelmedikçe devemiz elimize geçmeyecek. Son çağda devemizi, hikmeti kaybettiğimizde, üzerinde biz de vardık. Kendimizi bulmadıkça devemiz ele geçmeyecek, devemizi bulmadıkça kendimize gelemeyeceğiz" (Özel 2009a, 212). Atatürk'ün bağlamı farklı da olsa, 1923'te Konya gençleri ile yaptığı konuşmada sarf ettiği “.... milli benliğini bulamayan milletler başka milletlerin şikart-dır/avi olur" sözü, hangi sebepten söylenmiş olursa olsun bu söz, millet bilincinin oluşması bakımından Özel'in, Türk Milletinin kendine gelmesi konusundaki hassasiyetinin ya da dokunduğu alanın ne kadar önemli olduğunun gerekçesini ortaya sermesi bakımından önemlidir (Atatürk Kültür, Dil Tarih Yüksek Kurumu 1997, 147)

Özel'in temel önermelerinden biri, Türklerin "tarihe dâhil olması" veya dünya tarihinin görünür yerinde olmalarının en önemli sebebi, onların Müslüman olmalarıdır. 13. yüzyılda Anadolu toprakları "Dar-ül İslam" beldesi olmasaydı Türklerin de vatanı olamayacaktı, iddiasını ileri sürmektedir (Aytekin 2014). Aynı şekilde, 1914-18 yıllarında dünya sisteminin "Türk'ü tarihten, Türkiyeyi haritadan silmek isteği”" ortaya çıkınca, İstiklal Marşının hedef olarak gösterdiği İslam ideolojisinin sağladığı motivasyon ikinci kez bu toprakların İslam beldesi olarak kalmasını temin etti (Özel 2013, 38). Başka bir röportajında Özel, halktan bilinçli olarak saklandığını iddia ettiği şu yargıyı ileri sürmektedir: "Biz İstiklal Harbini Müslüman olduğumuz için başardık" (Özel 2010a, 414). Ona göre, Türkiye hangi sebeple Türk milletinin anavatanı olmuş ise aynı sebebe bağlanmak sureti ile dünya sisteminin küresel kültürel taarruzunu gelecekte de püskürtebilecektir. Özel'in bu bağlamdaki düşüncelerine dayanak 
olacak nitelikte bir görüşü Cemil Meriç’te görmek mümkündür. Meriç’e göre, "Türk insanının Avrupa karşısında birliğini sağlayan tek bağ İslam'dır". Bu sebeple Avrupa var gücüyle İslam'a saldırmakta, onu Türklükten ayırmaya çalışmaktadır (Meriç 1993, 170). Bu düşüncelerin karşıt kutbu olan Avrupa tarafından çek etme imkânı mevcuttur. Edward Said'e göre, yedinci yüzyıldan 1571 İnebahtı Savaşı'na kadar İslam, İster Arap, İster Osmanlı, İster Kuzey Afrikalı ve isterse İspanyol şeklinde görünsün Hıristiyan Avrupa'ya karşı devamlı bir tehlike unsuru olarak algılanmıştır (Said 1998, 112). 1571 İnebahtı Deniz Savaşı'ndan sonra Türklerin/ Müslümanların yenilebileceği fikrinin ilk defa Avrupa tarafından tecrübe edildiğini hesaba kattığımızda, Özel’in Türk/İslam eşitlemesinin önemi büsbütün ortaya çıkmaktadır.

Türklük/Müslümanlık meselesini, bu topraklarda bir milletin yaşayıp yaşamadığı, bu toprakların bir milletin vatanı olup olmadığı meselesi olarak bakan İsmet Özel'in Türk/ Müslüman eşitlemesinin ilk örneğini ebeveynleri Kürt olarak bilinen ve bazı metinlerinde Said'i Kürd'i ismini kullanan Said Nursi'de görülmesi ilginç olmanın ötesinde, dış tehlikenin büyüklüğü karşısında tesanüd duygusu ve düşüncesinde Türkiye için İslam'dan başka dayanak noktasının olmadığını faş etmesi bakımından dikkate değer bulunmaktadır:

“Ey Türk kardeş! ... Senin milliyetin İslamiyet'le imtizaç etmiş, Ondan kabil-i tefrik değil. Tefrik etsen mahfsin!,,...Türkün hakiki bütün mefahir-i milliyesini taşıyan İslamiyet milliyetinden çıkmak isteyen adamları Türk bilmiyoruz. Türk perdesi altına girmiş Frenk telakkki ediyoruz" (Kara 1987, 339-52).

"Özel'de: Tarih içinde Türklerin olanca girişim gücü Müslümanlık damgası taşır. Yirminci Hıristiyan asrın başlarında İstiklal Harbi'ne damgayı Türklük ve Müslümanlık birlikte vurdu. Cumhuriyet tarihi boyunca bu ikisi arasina mesafe koyanlar, her ikisine de olan husumetlerini gizleyenler oldu hep" (Özel 2015, 37).

B. Lewis, "İslamlığı kabul eden uluslararasında hiç biri, kendi ayrı özdeşliğini İslam Ümmeti içinde eritmekte, Türklerden daha ileri gitmedi". Türkler Müslümanllğa geçtikten sonra, Türk ile Türk olmayan arasında hiçbir ırk ayırımını makbul bir edebi söylem olarak kabul etmediler (Lewis 2000, 327). Anadolu toprakları asırlarca İslam ile yoğrulmasına bağlı olarak, din ile millet kavramlarının özdeşleşmesine yol açmıştır. Bu sebeple Özel, Türkü: "dini denilince milliyeti, milliyeti denilince dini anlaşılan" olarak tanımlamaktadır (Özel 2013, 42). Bunun yanında Özel, Türk ayrı Müslüman ayrı tezlerinin batılıların desteğiyle Macarlar eliyle tedavüle sokulduğunu, İslam'dan kopuk bir Türklügün modernleşme politikaları çerçevesinde, Cumhuriyet dönemi yöneticilerine önerildiğini ve bu yöneticilerin İslam öncesi dönemdeki Türk'e dikkatlerinin çekildiğini vurgulamaktadır. Bu çerçevede Batı yörüngesinde siyasal, kültürel ve sosyal politikalar uygulayan Cumhuriyet dönemi elitleri, başta Türkçe'nin İslam'dan arındırılması yönünde teoriler ürettiler. Sonra devrimlerle Türk'ün İslam ile irtibatlı nesi varsa itina ile temizleme yoluna gittiler (Özel 2010c, 167). Tanzimat'la başlayan, İkinci Meşrutiyetle ekonomik ve sosyal bir muhteva kazanan ve Cumhuriyetle radikal bir tutum bürünen batılılaşma politikalarıyla, Türkiye dâhil olduğu otantik kültür dairesinden çıkarak yeni bir kültür dairesine geçti (Özel 2009b, 217). Özel'in bu tespitlerinin çapraz okumasını Ç. Keyder de görmek mümkündür. Keyder, Cumhuriyet döneminin yukarıdan modernleştirme çabalarını, Hıristiyan burjuvazi tarafından başlatılan kültürel filizlenme yerine milliyetçi bir ideoloji koyma girişimi olarak görmektedir. Zaten milliyetçilik ideolojisi de 19. yüzyıl Avrupa'sında gecikmiş devletler için özel olarak terkip edilmiş bir modernleştirme ideolojisi olarak kurgulanmıştı (Keyder 2003, 125). Birçok araştırmacı tarafından tarihsel verilerle teslim edilen Türk ile İslam arasındaki 
özdeşlik ilişkisi, Özel'in 2000'lerden sonraki düşüncelerinin temel eksenine oturmuştur. Bu sebeple Özel, Türk/İslam kavramının tarihsel süreçte kazandığı anlamı açıklamakla işe başlayarak daha esaslı bir paradigmanın temellerini atmaktadır.

Özel, "Türkiye Türklerindir" demenin kolay olduğunu; ama kime "Türk” denileceğine karar vermenin pek kolay olmadığına dikkat çekmektedir. Bu çerçevede Cumhuriyet idaresinin, "etnik ve demografik Müslümanlı̆̆g" Türklük olarak açıklamayı konjonktür gereği elverişli bulduğunu açıklamaktadır. Türklük, bir şekilde belli olacaksa göz rengi veya ten rengiyle, kafatası ölçüsüyle, soy ağacıyla belli olmayacağını; Türklüğün, ancak tutulan taraf ile belli olacağını, Türkün tarihte tuttuğu tarafın da bir nevi "ila-yl kelimetullah" istikametinde olduğunu öne sürmektedir. "Türklük, ayrı; Müslümanlık ayrı diyenler, gerçekte hangi tarafi tuttuklarını saklamak isteyenlerdir" gibi önermelerle Türk'ün, ayırt edici özelliğine ve tarihte tuttuğu role dikkat çekmektedir (Özel 2011a, 84). Bu çalışmada, Özel'in düşüncesinde, bir bakıma tam tanımda (ağyarını mani efradını cami) olduğu gibi tanımlanan "Türk" kavramının, gerçekten bu anlamda kullanılıp kullanılmadığına dair genel olarak Özel'in metinlerinden tarihsel bir iz sürülmektedir.

Bu çerçevede, Özel "Türk" kelimesinin tarih boyunca kazandığı anlamı; bugünü aydınlatmak, Türkiye'nin aidiyet çatısının nerde kurulabileceğini, geleceğinin nerede olduğunu belirginleştirmek ve bir ölçüde çıkış yolunu imlemek için açıklamaktadır. O, "tarihi olmayanın talihsizliğe" uğrayacağını iddia ederek, "Türk" kelimesini belli bir tutuma, tavra sahip insanın tarihte aldığ1 rol olarak görmeyi tercih etmektedir (Özel 2010b, 231). "Türk" kelimesini, Türkler için ilk kullananların Çinliler olduğu kayıtlarda görülmektedir. Çinliler, Avrupalıların modern dönemde kapitalizmin karşısında duranlar için kullandığı medeniyet düşmanı söylemini çağrıştıran bir anlamda "barbar" kelimesi ile eş anlamda "Türk" kelimesini kullanmışlar. Çünkü ilk medeniyeti kuran Çinliler, kendi kalıplaşmış donmuş kurumlarını, yani medeniyetlerini yıkmaya gelen Türkleri "barbar!" yani, medeniyet aleyhtarı anlamında isimlendirdiler. Türkler ise kendilerini, "Török" kelimesi ile isimlendirdiler. "Török" kelimesi töresi olan, töreye uygun, "erk" anlamını da içeren bir terim olarak görülmektedir. Török kelimesin yanında bir de "Tat" kelimesi, yani töresi olmayan ya da töreye uymayan anlamında kullanılmıştır (Özel 2010a, 421).

Çinlilerin "Türk" terimini tanımlamalarına benzer bir tanımlamayı tarih boyunca Türklerle komşuluk ve mücadele ilişkisini sürdüren kavimlerden biri olarak İranlılarda görmek mümkündür. Özel, tarihsel olarak Talas Savaşı'ndan sonra Araplara karşı savaşan Çinliler karşısında yer alan bozkır kabileleri, yani Talas Savaşı sırasında ve sonrasında Arapların/ Müslümanların yanında yer alarak İslâm'la karşılaşan bozkır kavimleri, bu hadiseden sonra kavmi birtakım vasıflar edindiklerini belirtir. İslâm'la tanışmış olmaları bozkır kabilelerini aynı zamanda birer kavim haline getirdi, ondan sonra birtakım Türkî, Türkik kavimlerden söz edilmeye başlandığını, bunlardan bir tanesinin de Türkmenler olduğunu ifade eder. Türkmenlerin öteden beri Türkmen olarak anılan insanlar olmadığını, İslâm'la karşılaşan unsurlar arasında Türk'e en çok benzeyenler onlar olduğu için Farsça tabiriyle "Türk-mânend" olarak anıldıklarını ileri sürer. Türk-mânend ("Mânend", kelimesi Fars Dili ve kültüründen fazlası ile etkilenen ve yoğun olarak Doğu Anadolu Bölgesi, Elazığ, Bingöl, Diyarbakır ve ilçelerinde yaşayan "Zazaların" dili olan "Zazaca'da" hala günlük yaşamda "benzemek" anlamında kullanılmaktadır.): Türk'e benzer, Türk gibi olarak anılmaya başlandığını ifade eder. Bu sebeple Özel'in Türk tasavvurunda, biyolojik, genetik olarak Türk ırkından olmamalarına rağmen, Türk gibi kâfir otoritesine karşı duran ve onunla çatışmayı göze alan her Müslüman Türk olarak kabul edilebilir/edilmelidir (Aytekin 2014). Özel, Türk ayrı Müslümanlık ayrı tezini, kâfirlerin söylem gücü sayesinde bize yutturduğu ve Türk milletinin mahvına sebep olabilecek kadar tehlikeli bir 
düşünce olarak nitelemektedir (Özel 2010c, 167). İslam'dan arındırılmış Türkçülüğün Batının etkisinde geliştiği iddiasında bulunan Özel'in düşüncelerini destekleyen bilimsel verilerin izini Çağlar Keyder'de görmek mümkündür. Keyder, İmparatorluğa Anadolu dışından gelen ve Türk milliyetçiliğinin muharrik gücü olan ideologların milliyetçi formasyonlarını büyük ölçüde Avrupa'dan edindiklerini ifade etmektedir (Keyder 2003, 87). Bu destek sadece İttihat ve Terakki dönemi ile sınırlı olmadığını, Cumhuriyet döneminde de sürdüğünü, 1921 gelindiğinde Fransız basınında Mustafa Kemal'i "Batı'nın nesnel müttefiği” olarak alkışlandığını, bunun yanında Rusya'nın bile Cumhuriyet yönetimine mali ve silah yardımında bulunarak, "milliyetçi hareketi" desteklediğini ileri sürmektedir (Keyder 2003, 105).

Dolayısıyla İslâm'la tanışan o bozkır ahalisi içinde önce Türk'e benzer oldukları için Türkmenler, sonra da kaldıkları yere göre nispet edilerek veyahut hükümdarlarına nispet edilerek birtakım kavimler doğmuş. Bu bakımdan Türk olmayı kabul etmeyenlere "Tat" denilmiştir. Talas Muharebesi'nden sonra fevç fevç insanlar İslâm'a girdiklerinde bazıları Müslüman olmamış, eski hallerinde kalmışlar. Özel'e göre, onların "Kalmuk" ismi ile anılmalarının sebebi Türkçe kelime olan "kalmak" sözcüğü ile doğrudan irtibatları vardır. Özel, bu durumu açıklamak için çok ünlü bir isme dayanan şu ilginç örneği vermektedir. O, Vladimir Ilyich Ulyanov Lenin'in babasının bir "Kalmuk" olduğunu kayda geçirmektedir (Özel, Ocak 2011).

Özel, "Bozkır ahalisi içinde karakter üstünlügü ile dikkati çekenler Türk olarak adlandırllmış", ifadesi ile biyolojik, genetik, fiziki özellikleri dışarıda tutmakta, buna karşılık sonradan tarihsel ve kültürel olarak kazanılan özellikleri önemsemektedir (Özel, Ocak 2011). Bazı konuşmalarında Özel, sosyolojik ve kültürel özelliklerin bile Türkü tanımlamada eksik kalacağını kati bir tavırla ifade etmektedir. Burada, nasıl ki herhangi bir olay karşısında şahsiyetin/kişinin bütünsel benlik/kendilik adına aldığ 1 tavır veya tutum onun kişilik değerleri, hatta en üste tuttuğu kişilik değerlerinden bağımsız düşünülemez ise aynı biçimde benzer bir anlamı, “Türk'ün" tarihsel olaylar karşısında aldığı tavırla ilişkilendirmek, "Türk” kavramının açıklanmasında da yararlı olacaktır. Bu bakımdan Özel, “Türkü” Bir kavmin adı olarak değil, bir sıfat olarak görmenin daha doğru olacağı ifadesinin altını çizmektedir:

“...Dünya tarihi içinde kâfir otoritesine meydan okuyan bir özelliğimiz
var. Bu yüzden de damarlarımızda hangi kanın dolaştı̆̆ı değil, ahlâkımı-
zın ne olduğu bizim Türk olup olmadı̆̆ımızı tayin ediyor. Biz kâfirle
çatışmayı göze aldığımız kadar Türk'üz; anamızdan babamızdan "Türk”
olarak doğamıyoruz...” (Özel, Aralık 2009).

$\mathrm{Bu}$ gibi ifadelerle Özel, daha önce Ziya Gökalp'in saf rrk söylemlerinin “Türk” için muhal olduğuna ilişkin "secere atlarda aranır" sözünü akıllara getirse de veyahut Gökhan Çetinsaya'nın Davison ve Georgeon gibi düşünürlere dayandırarak, Türkçülügün iki temel ideologu olan Ziya Gökalp ve Yusuf Akçura gibi Türkçülerin tezlerinde "İslamı (modernist) olmazsa olmaz bir faktör olarak" görmesine rağmen, Özel'in diğer Milliyetçi düşünürlerin "Türk" kavramına yüklediği anlamdan tamamen farklı bir "Türk" algısına sahip olduğu ifade edilmelidir (Çetinsaya 2014, 420).

Buna karşılık biyoloji kökenli bir Türk felsefecisi/filozofu olarak öne çıkmış Teoman Duralı'nın, "Türk tarihi bir dava tarihidir. Bir soyu, bir ırkı, bir kavmi başat kılma davası değil" önermesi Özel'in düşüncesi ile bire bir örtüşmektedir (Dural1 2013). Bu sebeple Özel'in Türk mefkûresinde, İslam'dan önce, kendisini biyolojik, genetik özelliklerle öne çıkaran 1rkî unsura ve dünya sistemi yörüngesinde ona boyun eğerek ya da onunla uzlaşarak alan bulmaya çalışan 
modern/nation anlamında Türk'e yer olmadığı açıkça görülmektedir. O, açıkça kâfirle çatışmayı göze olan Müslümana Türk demeyi yeğlemektedir. Bu çerçevede Özel'in Türklük kavramına yüklediği anlamın izi, ne Akçura, ne Gökalp, ne de Atsız da görülebilir. Çünkü bu üç ismin Türkçülüğü, büyük ölçüde Batıyı model alan, dünya sisteminin öngördüğü, yol verdiği ve esasta asıl Türkü dünya sistemi lehine ehlileştiren bir yönelimi işaret etmeleri bakımından Özel'in Türklük algısına uzak görünmektedirler. Özel, bu tarz Türkçü söylemleri, dünya sistemi dolayımında "icat edilmiş Türk" olarak nitelemektedir (Özel 2013, 73). Özel'in bu bağlamdaki fikirlerinin çapraz okumasını, Lewis'te görmek mümkündür. Lewis'e göre, Avrupa üniversitelerinde 18. yüzyılda kurulan Türkoloji bölümleri daha çok, İslam'dan önceki Türklerin karanlık tarihlerine 1şık tutmaktadır (Lewis 2000, 242). Özel'in "Türklük" kavramına yaptığ1 vurguda; yerli, milli olana yönelmesi bakımından "Anadolu" kavramı üzerinden Nurettin Topçu'da (2010) ve İslami dozun yüksekliği bakımından M. Akif Ersoy'da izi görülebilir. Öte yandan millet kavramının yöntem bakımından temellendirilmesi açısından Yahya Kemal Beyatlı ile İsmet Özel'in Türk Milleti'nin oluşumunda "tarih ve coğrafya" vurguları arasında belli paralellikler görülmektedir. Ahmet Kabaklı'nın aktarımına göre Yahya Kemal, Leon Cahun ve Camille Jullian'ın etkisinde kalarak “Bin sene içinde Fransız toprağı Fransız milletini meydana getirdi" motto deyişine benzer bir tezin Türk milleti için geçerli olduğunu benimsemiş̧ir. Bu vesile ile Yahya Kemal "Milli tarihimizin basslangıcı olarak 1071 Malazgirt Muharebesini" görmektedir (Kabaklı 2017, 110). Öte yanda Bozkurt Güvenç'in (2006, 40) Sabahattin Eyyüpoğlu'ndan aktarımına göre "Biz şimdi hem Fatih, hem de fethedilmişiz!" bozkırdan gelen Oğuz boyları Anadolu'yu Türkleştirdi; ama bize bağrını açan Anadolu da bu göçerleri aldı, rençberlere dönüştürdü. Ava çıkan Türkler avlandılar".

Özel'in Türk tanımlaması çerçevesinde alışlagelen düşüncelere bağlı zihinleri kurcalayan ve karıştıran önemli bir mesele, tarihte Türk ismi ile anılan ilk Türk devleti olan "Göktürk" ile ilgili ironik açıklamasıdır. Bu bağlamda Özel, şu ilginç açıklamayı öne çıkarmaktadır:

"Türkler tanınmışlarsa, dereceleri, sosyal statüleri itibariyle ve mahiyetleri, ahlakî-itikadî özleri itibariyle tanınmışlardır. Diyeceksiniz ki o zaman Göktürklere ne diyeceğiz? Bakınız, onların da adı üstünde, onlara Göktürk demişler. Doğru, işte bir yerde Göktürkler var. Gagavuz adının da Gökoğuz'dan geldiği söyleniyor. Doğru bir adlandırma ile karşı karşıyayız. Göktürkler var, Gökoğuzlar var. Siz eğer Türkçe biliyorsanız gök kelimesinin olmamış anlamına geldiğini bilirsiniz. Göktürkler henüz gök olan Türklerdir. Aynı şekilde Gagavuzların da henüz gök olan Ŏguzlar olması gibi (Özel, Şubat 2007).

Bu açıklamalarıyla Özel, "Türk" kavramının Anadolu topraklarında ve İslamiyet ile birlikte biçim aldığını ifade etmektedir. "Türkün" aslı Orta Asya bozkırlarında değil, Anadolu'da "dünya sistemi veya kapitalizm" ile çatıştığı coğrafyalarda aranmalıdır. Bu bağlamda Özel (2010b 301), "Íslamiyet'ten önce Türk diye bir şey yoktur" önermesini israrla ileri sürmektedir. Bir milletin oluşmasında belirleyici olan faktörlerin başında gelen dilimizin oluşmasında dahi, dinimiz ırkımızdan önce gelir. Türkçenin İslam'dan etkilenen özellikleri çıkartılırsa geriye lisan sayılamayacak bir yapı kalır. "Türk milleti, İslam'a dayanarak oluşmuş bir millettir" (Özel 2011a, 154).

Dahası, "Türk" kelimesinin anlamını "özgürlük ve Müslümanlık" ile kazandığını ifade eden Özel, bu "özgürlük ve Müslümanlık" adına Türkiye denilen bir ülkenin doğduğunu ve Türk’e as1l şeklini veren yerin de Türkiye olduğunu israrla ifade etmektedir. Türkiye denilen toprakların Türkler tarafından "dar-ül İslam" haline getirildiğini, bir bakıma "Türkiye'nin Türkleri, 
Türklerin Türkiye'yi" husule getirdiği tezini ileri sürmektedir. Türk'e ait asıl özün Türkiye tarafından temsil edildiğini; çünkü "Dış Türk" tabirinin anlamlı olması ancak Türkiye'de mümkündür (Aytekin 2014). Örneğin Gagavuzlar, Tatarlar, Kırgızlar, vb. diğer Türkler, kendi haricindeki Türkler için bu kavramı, "dış Türk” kullanmaları ne anlamlıdır ne de mümkündür, tarih buna imkân vermemektedir. Bu bakımdan "Türk Türkiye'yi, Türkiye Türkü oluşturmuştur. Türkiyesiz Türk, Türksüz Türkiye olamaz” (Özel, Kasım 2014).

Türklerin İslamiyet ile tanışması sonucu, "İslamiyet Türk'ün kendini bilmesinin nişanesi olmuştur”. Özel'e (2010b, 72) göre, "bu nişanenin yerine başka bir şeyin konulabileceğini düşünmek abestir. Türklerin yalnızca tarih sahnesine çıkmaları değil, aynı zamanda o sahnenin en görünür kısminda yerlerini almalarını da, onların Müslüman olmalarına bağlamaktadır". Özel $(2012,15)$, Türkiye' de belli çevrelerin bütün tepkilerini göğüslemeye hazır bir vaziyette, “Türkiye'nin İslam dışı bir kimliğinin olamayacağı”, tezini ısrarla savunmaktadır. Bu bakımdan bir kartopunun tepeden yuvarlanarak çığa dönüşmesi gibi Türk kavramının da İslam ile yoğrularak ve Batı ile çatışarak Anadolu topraklarında oluştuğunu söylemek Özel'in metinleri ve söylemleri için aşırı bir yorum sayılmamalıdır. Bu tez, Atilla İlhan gibi sol şiir ve düşünce geleneğine mensup kişilerce de teyit edilmektedir: "Biz esas itibariyle İslam kültürü çevresinde bir kültürüz, bir milletiz. Ve çok başarıll büyük bir kültür ve değerler sistemi yapmışız OsmanlıSelçuklu döneminde" (Yeni Gündem Gazetesi 1984; Özel 2010a, 40). Buna benzer değerlendirmeleri Attilla İlhan, Özel ile yaptıkları başka programlarda da tekrar etmiştir. Elbette Özel'in düşüncesinde, İslam'ın Türk kültüründeki etkisi başka düşünürlerle kıyas edilemez, O bu durumu, şu netlikte ifade etmektedir:

"Biz Müslüman olduğumuz için millet olmuş bir topluluğuz ve bizim
külttürel olarak varlı̆̆ımızın ikinci bir teminatı yoktur. Millet meselesinde
Müslüman olmaktan başka tutacak hiçbir dalımız yok. Ve Müslümanlı̆̆ı-
mız elimizden alındığı zaman biz kendimizi izah edemeyiz. Yani bir millet
olmamızın bir izahatı bulunmaz" (Özel 2010b, 194).

Öte yandan üzüm üzüme baka baka kararır veya varlıklar zıtları ile kaimdir, düşüncelerinin elbette "Türk" kavramının anlamının belirginleşmesinde de yeri vardır. Ancak, bu bağlamda "Türk" kavramının anlamının netleşmesinde karşıtının/ötekisinin geç̧ekten kim veya ne olduğunun bilinmesi büsbütün önem arz etmektedir. Örneğin, Yunan kavramının anlam kazanmasında Türk yeterli bir sebeptir. Fakat "Türk" kavramının neye tekabül ettiğinin tam manasıyla bilinmesinde Yunan, çok silik bir unsur olarak kalmaktadır. Tek başına alındıklarında, Alman, İtalyan, Fransız, gibi birçokları için benzer bir durum söz konusudur. Bu çerçevede Türk ile batılılar iki farklı kültürü değil iki zıt kültürü, öyle ki varlıkları birbiri ile kaim iki zıt kültürü temsil etmektedirler. Bu karşılaştırmalarda Özel'in, Türk kavramını herhangi bir ulus olan Yunan, Alman, Fransız, İtalyan vd. farklı olarak konumlandırmasını hamasi söylemle ilişkilendirmek ya da yargılamak, ancak Avrupa tarihinde Türkün/Müslüman oynadığı tarihi rolü bilmemekle mümkün olabilir.

Klasik dönemde Çinlilerin ve İranlıların "Türk" kavramına yüklediği anlamın bir benzerini, Türklerin Anadolu'ya yerleşmeleri ile karşı karşıya kaldıkları, bugün Batı diye nitelenen o dönemlerde ise Hıristiyan Avrupa denilen toplumlarda da görmek mümkündür. Tarihsel olarak Türklerin Avrupa toplumları ile karşı karşıya gelmesi, karşıtlık ilişkisi olan iki siyasal, askeri gücün ya da etnikliğin karşılaşmasından daha fazla bir anlama işaret etmektedir. Bir bakıma "Türklük" Yunan'a, Alman'a, Fransız'a, İtalyan veya İngiliz'e karşı oluşmuş bir anlam bütünlüğünden ziyade bütün bu toplulukları birden, "Haçlı Ordusu" çatısı altında, Özel'in tabiri ile "İbrani-Hiristiyan, Grek-o-Roman" karşısına alarak konumlanmış bir üst oluşumu temsil 
etmektedir (Özel 2013, 41). Benzer bir durumu Özel, "dünya sistemi veya kapitalizm” için de iddia etmektedir. Birçok metninde veya konuşmasında Özel, "dünya sistemi veya kapitalizm" denilen oluşumu, Türkün tarihte doldurduğu boşluğa karşı oluşan itirazın neticesi olarak ortaya çıkmış, biçim almış yapılar olarak görmektedir. Daha net bir ifadeyle Özel (2010b, 307), kapitalistleşmeyi Türkleşmeye panzehir olsun diye Avrupalıların keşfettiği bir yapı veya süreç olarak nitelemektedir.

Özel (2011b, 73), çok şaşırtıcı bir biçimde şu tespitte bulunur. "Haçll seferleri Türklerin tarih sahnesinde tuttukları yere Avrupa'nın yaptı̆̆ itirazdır" şeklinde yorumlamaktadır. Bu bakımdan Ona göre, "Osmanlılar ne Almanya ne de Fransa ile savaştılar; Haçl ordulariyla savaştılar. Hem Niğbolu'da hem de Haçova'da karşılarında Haçlı orduları bulunuyordu. Yani Türklerin mağlup ettikleri orduların hepsi Haçlı ordularlydı". Bu bakımdan Özel'in düşüncesinde Türk milliyetçisinden, dünya sistemine karşı, onun yıkılması yönünde çaba sarf eden insanlar anlaşılmalıdır. Dünya sistemine karşı bir düzen arayışında olan Türkler, ancak Türk milliyetçisi olabilir. Dünya sisteminin yörüngesinde kalarak, onun işlerliğini sağlayarak Türk milliyetçi olunamaz. Çünkü dünya sistemi denilen oluşum, Türk'ün tarihte doldurduğu boşluğa yapılan itirazın ve Türkü gerileterek oluşmuş bir düzendir. Bu bakımdan Türk düzeni ile modern dünya sistemi denilen düzen iki farklı düzenden ziyade, iki zıt düzeni temsil etmektedir (Özel, Kasım 2014). Bahse konu bu iki zit kutubun en somut, görünür ve son hali Osmanlı İmparatorluğu ile "İbrani-Hıristiyan, Grek-o-Roman" karşıtlı̆̆ıdır. Lewis, Osmanlı devletini İslamlık ile Bizans Hıristiyanlığı arasındaki sınırda doğduğuna ve varoluş nedenini; sınır savaşçıları ve din adamları gibi iki temel unsura dayandığına dikkat çekmektedir (Lewis 2000, 26).

Mehmet Akif'in İstiklal Marşı'nda "Türk" kelimesini ve "Müslüman" kelimesini kullanmadan, bunların ikisinin yerine "kahraman ırkım" tabirini kullanarak dikkat çektiği anti-emperyalist duruş ile Özel'in "tarihi rol" kavramı çerçevesinde geliştirdiği düşünceleri arasında fark görülmemektedir. Sonuç olarak Özel için Türk kimliğinin kristalleşmesinde hiçbir millet oluşturucu faktör din kadar temel belirleyici olmamıştır. Türk olma bilinci, farkındalığ 1 ancak İslam dini ile buluşması sonucu temayüz etmiş bir şuur, bir karakter ve tarihi bir rol olarak ele alınabilir. Bu bakımdan Türk milletinin oluşmasında diyalojik karşıt hiçbir şekilde Fransız İhtilali sonrasında oluşmuş bir ulus veya tek devlet olamaz. Türk milletinin oluşmasında illa bir diyalojik karşıt aranacaksa bu, içinde bütün Avrupa uluslarının katkısı olan Haçlı İttifakı veya temelleri 14. yüzyılda İtalya site devletlerinde atılan ve daha sonra merkezi sirasıyla, Hollanda, İngiltere ve ABD'ye taşınan kapitalist dünya sisteminin olması tarihi bir zorunluluktur.

Özel'in, Türklügü̆n biyolojik kökenle ilişkisinin olmadığına, tamamen bir karakter özelliği olduğuna dair düşüncesinin berraklaştığı bir örnek de, onun Türklüğün tarihi bir rol olarak "Dırar mescidinin" yıkılışı ile başladığı hususundaki yorumudur. Bilindiği gibi, Tebük Savaş1 hazırlıkları yapılırken, bir tarafta Hz. Peygamberle beraber canını, malını ve tüm varlığını feda etmeye hazır Müslümanlar, öbür tarafta Peygamberin yanında savaşmaktan sakınan, bazı bahanelerle kaytarma niyetinde olan insanlar/münafıklar vardır. Münafıklar, yağmurlu ve soğuk kış gecelerinde hasta, özürlü ve yaşlıların rahat namaz kılmaları için bir mescit inşa ettiklerini ve bir nevi mescidin ibadete açılış meşruiyetini sağlamak için Hz. Peygambere namaz kıldırması için ricada bulunurlar. Tebük Savaşı için hazırlık yapan Peygamber, namaz kılmak! gibi gayet masum görünen bu rica üzerine, sefer dönüşünde namazı kıldırabileceğini söyler. Tebük Seferi dönüşünde Peygambere Tevbe süresininin 107-110 ayetleri nazil olur. Bu ayetlerde mealen "Dırar mescidini" yapanların niyetinin kâfirlerle açıktan savaşmak yerine onlardan yardım beklemek ve Müslümanlar arasına nifak sokmak olduğu ifade edilir. Bunun 
yanında Münafiklar yemin etseler bile onlara inanılmaması gerektiği ve "Dırar Mescidinde" asla namaz k1lmamas1, namazlara "Kuba Mescidi" ve "Mescidi Nebevide" devam etmesi yönünde Hz. Peygamber uyarılır. Bu ayetlerin nüzulünden sonra Peygamber efendimiz " Dırar mescidinin" yıkılmasını emreder (İslam Ansiklopedisi (n.d.), 272).

Bu örnek olayda Özel için Türklük, "Dırar mescidini" inşaa edenlerin karşısında; Hz. Peygamberle beraber canını, malını ve tüm varlığını feda etmeye hazır Müslümanların kâfire karşı mücadeleden yana tercihte bulunanlarda aranmalıdır. Birçok konuşmasında ve yazısında Türklügün başlangıç yeri olarak "Dırar mescidine" atıfta bulunan Özel'in düşünce sisteminde "Türklük" veya "Türk milleti" kavramına kavmi/ırkî bir nitelik/atıf hiçbir surette söz konusu değildir. Bu sebeple Özel de Mehmet Akif gibi kavmini öne sürmenin küfür olduğunu açıkça beyan etmektedir (Akif'in Safahat'ta zikrettiği; "Nizâr evlâdl: Yetişin ey Nizâr oğulları! Yemenliler de: Yetişin ey Kahtan oğulları! dedi mi, hemen tepelerine felâket iner; hemen Allah'ın nusreti üzerlerinden kalkar; hepsine birden de kllıç musallat olur" Hadis-i şerifi yorumlamak için yazdığı, "hani milliyetin Íslam idi", dizesi ile bilinen şu şiirini, kendi düşünceleri için esas olduğunu ifade etmektedir: “...Hani, milliyetin İslâm idi... Kavmiyet ne! Sarllıp sımsık dursaydın ya milliyetine. "Arnavut" ne demek? Var mı şeriatta yeri? Küfr olur, başka değil, kavmini sürmek ileri ...” (Ersoy 1993, 265-266).):

“...Hani, milliyetin İslâm idi... Kavmiyet ne! Sarllip sımsıkı dursaydın ya milliyetine. "Arnavut" ne demek? Var mı şeriatta yeri? Küfr olur, başka değil, kavmini sürmek ileri" (Ersoy 1993, 265-6).

"Türklük bir karakterdir, bir vasıftır, bir kavmin adı değildir. Kara derili bir Türk olur, mavi gözlü ve sarışın bir Türk olur. Türklük asla babanın, ananın dölüyle alakalı bir şey değildir. Tarih içinde cihadı şarta bağlamayan Müslüman'a cinsine, soyuna sopuna bakılmaksızın Türk denmiş" (Özel, Şubat 2011).

Özel, şairlere ve filozoflara özgü bir tavırla, dilin mevcut anlam ilişkilerini kullanmanın yanında, yepyeni bir dil oluşturma ve kelimelere yeni anlamlar yükleyerek alışılagelenin dişında yeni bir söylem geliştirmektedir. Bu yönüyle "Türk" kavramını hem modern dönemde Batılı söylemde kullanılan anlamını hem de geleneksel Türk milliyetçilerinin kullandığ1 anlamını dekonstrüksiyona uğratarak, kavramın içeriğini yeniden hazırlamaktadır. Bu çerçevede Özel, Türklüğü, ırk, kavim, biyolojik, antropolojik/fiziki özellikler gibi doğuştan sahip olunan bütün genetik donanımların dışarda tutulduğu; buna karşılık, tarihsel bir olgu olarak kâfirle çatışmayı göze alan, kendi topraklarında kâfir otoritesini kabul etmeyen ve ilay-1 kelimetullah bayrağını istiklale çıkaran her türlü çabayı bir sıfat olarak Türklük kapsamında değerlendirmekte olduğu anlaşılmaktadır. Bu bağlamda Özel, Arapların İslam'ın yükünü taşıdığı zamanlarda onların da "Türk" olarak kabul edilmesi gerektiğini dile getirmektedir (Özel 2010b, 219). Bu açıklamadan da anlaşıldığı gibi Özel, Türklüğü kâfirle çatışmayı göze alan Müslüman'ın bir sıfatı/takva olarak görmektedir. Türklerin İslam'dan önceki dönemlerini veyahut Fransız İhtilalinden sonra modern dönemde nation/millet olarak İslam'dan uzak, rrki özellikleri ile öne çıkarılması düşüncesinin bu topraklarda yayılmasını, batılılar eli ile bilinçli olarak üretilmiş bir söylem olarak görmektedir. Bu bağlamda saf ırk tartışmalarında olduğu gibi, Türk ırkı diye biyolojik temelli bir iddianın tarihin hiç bir döneminde var olmadığını ileri sürmektedir (Özel 2010c, 167).

Özel (2010b, 299), Batılı söylemin etkisinde oluşturulan Türklük kavramının negatifliğini vurgulayarak, Orhun Yazıtları'na başvurarak veya atasözündeki, “al turpu vur Türk'e yazık oldu al turpa" olumsuz anlamıyla Türklük kavramını bu milletin kendisini tanımlamada yakıştırıp 
kullanmadığını fakat çok sonraları tarihi bir tavrın adı olarak Hıristiyanlıkla Haçlı Seferleri ile girilen çatışmaların sonuncunda "Türk, bir millet adl" ve tarihi bir davanın/1lay-1 kelimetullah aracı olarak benimsendiğini tespit etmektedir.

Özel, Anadolu topraklarının hem 13. yüzyılda hem de 20. yüzyılın başında Türklerin elinde kalmasının İslam dini dışında açıklanabilme imkânının olmadığını vurgulayarak, "Biz İstiklal Harbini Müslüman olduğumuz için verdik. Bunun başka hiçbir izahı yoktur" iddiasını ileri sürmektedir. Türkler, Mmüslüman olduğu için millet olmuş bir topluluktur. Türkün, kültürel olarak varlığının birinci teminatı Müslümanlığıdır. "Millet meselesinde Müslüman olmaktan başka tutacak hiçbir dalımız yok. Müslümanlığımız elimizden alındığı zaman biz kendimizi izah edemeyiz, yani bir millet olmamızın bir izahatı bulunamaz" (Özel 2010b, 193-4). Ona göre, dünya tarihinde "Kavmi ve dini ayn olan, dinini milliyeti haline getiren tek millet Türk milletidir" (Özel 2010b, 302). Bu fikirleri ile Özel, Türk milletinin oluşturucu mayasını İslam'la açıklamanın yanında, gelecekte de varlığını sürdürmesinin aynı sebebe bağlı olduğunun altını çizmektedir. $\mathrm{Bu}$ önermelerin yansıması olarak Özel, kendi Müslümanlığı ile Türkçülüğü arasında bir mesafe görmemektedir (Özel 2010c, 69).

\section{Sonuç}

Bu çalışmada İsmet Özel yazılarında 2000'den sonra merkezi yeri işkâl eden temel kavramlarından biri olan millet kavramı üzerinde duruldu. Onun "Türk", "Türk milleti" ve "biz Türkler" gibi kavramların etrafında geliştirdiği düşünceleri incelendi. Özel, "Türk'ün, Türkçe'nin ve Türklügün" Anadolu topraklarında 11. yüzyıldan sonra İslam dini ile irtibatlı olarak tarih ve coğrafyaya bağl1 bir şekilde bu topraklarda oluştuğu tezini öne sürmektedir. Bu sebeple "dış Türkler" kavramı Anadolu dışında kalan Türkleri ifade etmek için sadece Türkiye'de kullanımı anlamlıdır. Çünkü Anadolu topraklarında bilhassa Batı'yla girdiği diyalojik ilişki ve tarihsel rolü itibariyle Anadolu da oluşan "Türk" nevi şahsına münhasır özellikler taşımaktadır. Anadolu da oluşan Türklüğün başat karakteri tartışmasız İslam'dır. Bu durum gerek sosyal, gerek kültürel ve gerekse dil itibariyle olsun, her alanda kendini hissettirmektedir.

İsmet Özel'e göre Türklük meselesi, bu topraklarda bir milletin yaşayıp yaşamadığı, bu toprakların bir milletin vatanı olup olmadığı meselesidir. Bu bakımdan Türklük Müslümanlıktan asla kopartılamaz (Özel 2010a, 277). Özel'in Türklük bahsinde tartıştı̆g meselenin izini Mehmet Akif'in İstiklal Marşında görmek mümkündür. Özel, İstiklal Marşı'nın Türk Milletinin mutabakat metni olarak Türkiye için ideolojik bir hedef tayin ettiğini, ancak Cumhuriyet elitlerinin bunun tam tersi istikamette politikalar uyguladığını ileri sürmektedir. Büyük ölçüde dünya sistemi yörüngesinde uygulama imkânı bulan Cumhuriyet dönemi radikal modernleşme politikaları neticesinde, Türk Milleti'nin varlık sebebi olan tarihi geçmişi itina ile temizlenmeye maruz kalmıştır. İstiklal Marşının, bir İslam devleti olarak kurulan Türkiye için işaret ettiği hedef, "Bu ezanlar ki, şehadetleri dinin temeli, ebedi yurdumun üstünde inlemeli" dizesi ile faş olmaktadır. Ancak Cumhuriyet dönemi modernleşme politikaları tam tersi bir istikamette ilerlemiş, işaret edilen ezanlar 18 yıl boyunca yasaklanacak kadar kati bir tutum almıştır (Özel 2010c, 119). Bütün bu yapılanları, Tanzimat'la başlayan ve Cumhuriyet rejimiyle hızlanan/ radikalleşen modernleşme politikaları bağlamında, icat edilmiş veya inşa edilmiş Türklük yorumunun neticesi olarak görmek mümkündür. Ancak bunun yanında; Tanzimat ve Cumhuriyet dönemi yöneticilerinin, Türkiye sınırları içinde, ihanete varacak düzeyde, bir "milletin" dirilişine mani olacak kültür politikaları güttüğü şeklinde değerlendirmek, Özel'in metinlerinde mümkün görünmektedir (Özel 2013, 73; 2015, 106-7). Özel, daha açık ve sert bir ifade ile bu durumu şöyle açıklamaktadır: 
Avrupalıların "nation" olarak tesmiye ettikleri kavramın bizim millet bütünlüğ̈̈müze teşmil edilmesinden kazanç sağlayanlar milli varlı̆̆ımızı kemirdi, somurdu, kuruttu (Özel 2013, 104).

Kabaklı'nın Cumhuriyet döneminin kültür, kimlik politikalarına yönelik, "Bizi kökümüzden koparıp, kütük gibi yol kenarına koydular" eleştirisinin dozu Özel'de daha artmaktadır. Cumhuriyet döneminin eşit yurttaşlık ve hukuki bağlılık iddialarının yanında daha çok ırk temelli vatandaşlık söylemi üzerine kurguladığı ulusal kimlik politikalarını, Türk milletinin yakın tarihi ile ilgili bilhassa dini kodları silmeyi hedeflemesi nedeniyle Özel Tarafından ciddi eleştiri konusu yapılmaktadır. Dünya sistemi yörüngesinde modernleşme politikalarının radikalleştiği Cumhuriyet dönemi, Türklerin bir millet şuuruna ulaşması ve tarih sahnesinin en görünür yerlerini tutmalarına sebep olan İslam dini ile olan bağları, önce dillerini/yazılarını ellerinden alarak ve sonra "mücerret bir Türk" oluşturma çabasıyla, İslam'ın Türke kazandırdıklarının inkârı ve reddi yönünde politikaların önü açıldı (Özel 2015, 108). Bu bakımdan İslamcilar Cumhuriyet'in kuruluşundan 1990'lara kadar Türkiye'nin yönetiminde ancak sağ siyasal iktidarlar arasında minör konumda yer bulabilmekteydiler. İslamcılar, ancak 2000'li y1llardan sonra Türkiye'nin yönetiminde merkezi konuma ulaşabildiler. Özel, Türkiye'nin yönetiminde İslamcıların merkezi konum almasını Dünya Sistemi'nin ulus-devletleri hizaya çekmesi bağlamında değerlendirdiğinden sorunlu olarak nitelemektedir.

Bu çerçevede Özel, bütün dikkatleri tekrar İstiklal Harbi'nde olduğu gibi İstiklal Marşı'mıza çekmektedir. Türkiye'nin bir medeniyetin ben idraki bağlamında çıkış yolu bulması, kurtuluşunun sağlam temellere dayanması, bağımsız olması, kendine gelmesi, kendi olması, kendi kalması gibi hedeflere dair kodların İstiklal Marşı'mızda tayin edildiğini; fakat bir şekilde, Cumhuriyet tarihi boyunca ipleri ellerinde bulunduran yöneticilerin, İstiklal Marşı'mızın öngördüğü hedeflerin hilafına uygulamaları, pratikleri yürüttüğünü gözler önüne sermektedir. Bu bakımdan İstiklâl Marşı'nın varlık sebebi ile Türkiye'nin yönetilme biçimi arasında siyasal kodların uyuşmazlığ s sorununun, Cumhuriyet dönemi boyunca devam ettiği görülmektedir. Özel'e göre, Cumhuriyet dönemi politikaları Türk Milleti'nin nereye ait olduğu konusunda milleti belirsizliğe sürüklemiştir (Özel, Aralık 2009). Yani, İstiklâl Marşı metni bu milletin mutabakat metni olarak kabul edilmediği için, milletin nereye tutunacağı konusunda belirsizlik, aynı zamanda top yekün milletin hedefsiz bırakılması anlamına gelmektedir. Bu tespitlerle bir bakıma Özel, modernleşme ve küreselleşme politikalarının pençesinde "muallâkta" bırakılan Türkiye'nin, bu belirsizlikten kurtulmasının ancak İstiklal Marşı'mıza tutunmakla mümkün olacağını, Türk efkâr-1 umumiyesinin istifadesine sunmaktadır.

Özel, Türkiye'de yaşayan insanların "istiklalini” veya bir çıkış yolunu bulma şartını, milli bir şuura varmaya, yeniden bir millet bilincine ulaşmaya bağlamaktadır. "Biz ancak bir millet olarak bütün belalarl savabilir, bütün nimetlerden istifade edebiliriz. Bizim bugün trafik problemi de dâhil olmak üzere meselelerimizi çözemeyişimizin nedeni hangi millete mensup olduğumuz konusundaki cehaletimizdir ya da bizi kandırmış olmalarına boyun eğmemizdir" (Özel 2010b, 203). Milletin dirilişi veya inşası bakımından Özel'in çabası, Müslümanların takva konusunda, öte dünyanın ebedi olduğu ve bu dünyanın alçaklı̆̆ı! yanında geçici olduğu bilincinin pekiştirilmesi; agâh bir Müslüman olarak neyin lehimize nelerin de aleyhimize olduğuna dair ahlaki titizliğimizi yeniden hatırlayıp, onunla amel etme yönünde Müslümanların asr-1 saadet veya Peygamberin yanındaki hallerine yeniden dönmeleri, güncel bir söyleyişle fabrika ayarlarına dönüşü gibi bazı hassasiyetlerin yeniden hatırlatılması ile ilgili olarak yorumlanabilir.

Özel'in Türk-Müslüman eşitlemesi veya Türklüğü bir sentez olarak görmesi, Türk kavra- 
mını İslam'ın mümessili, dünyalık olanın değil ahiretin hesabını yapan, kâfirle çatışmayı göze alıp onunla savaşmayı önemseyen tarihi bir rol olarak "takvayl" esas alan nitelemesi gibi İslami vurgular, Türkiye'nin toplumsal bütünleşmesine sahici bir stratejik temel sağlamasına rağmen, farklı toplumsal kesimlerde aşırı tepkilere de yol açtığı aşikârdır.

Özel (2010-I, 277), milli kimliğimizin dini vasıflarımızdan koparılamayacağını, koparıldığı takdirde kimliksiz, şemsiyesiz veya çatısız kalacağımızı; bir bakıma küresel kasırgaların estiği bir dönemde çatısız kalan evimizin içindeki hazineler ne kadar kıymetli olursa olsun onları korumanın imkân sınırlarını zorlayacağını imlemektedir. Türklük meselesi, bu topraklarda bir milletin yaşayıp yaşamadığı, bu toprakların bir milletin vatanı olup olmadığ meselesidir $\mathrm{Bu}$ bağlamda Özel, İsmet İnönü’nün Lozan'dan çıkarken “Bir 100 sene kazandık” sözünü hatırlatarak, Türkiye'nin fiziki varlığının karşı karşıya olduğu tehlikeye dikkatleri çekerek; bu tehlikelerin bertaraf edilmesinin, Türkiyenin bir devlet olarak varlığını devam ettirebilmesini doğrudan "millet meselesine" bağlamaktadır (Özel 2010b, 317). Bir vatanın kurulması ve korunmasında şairlerin gücü yadsınamaz. Aynı zamanda bir vatanın oluşumunda ve bekasında lisanın/söylemin gücü ortadadır. Motto deyişle lisanı olmayanın vatanının olmayacağı gibi lisansız vatan da olmaz. Vatan savunmasında son söz elbette milletindir, ancak söylenecek sözün içerik ve biçimini, o toplumun şair ve filozofları tayin eder. Bir toplumdaki bel kırıklığını ilk fark edenler şairler ve filozoflardır. Aynı şekilde bir toplumun, milletin anlaşılmasında söz şairlere ve filozoflara düşer, çünkü toplum ve milletin kuruluşu o toplumun şair ve filozoflarına dayanır, bilim ve bilim adamına ancak meseleyi açıklamak düşer.

\section{KAYNAKÇA}

Anderson B. (2009). Hayali Cemaatler. İstanbul 2009.

Atatürk Kültür, Dil Tarih Yüksek Kurumu (1997). Atatürk'ün Söylev ve Demeçleri I-III. Ankara 1997. Yeni Gündem Gazetesi (1984, Say1 9, 1-15 Eylül). "Attilla İlhan: İslam Kültüründen Geliyoruz”.

Aytekin A. (2014). Ulus-Devlet Ve Küreselleşme Bağlamında İsmet Özel'in Toplum, Millet ve Vatan Tasavvuru. Yayımlanmamış Doktora Tezi. Süleyman Demirel Üniversitesi, Isparta 2014.

Çetinsaya G. (2014). “İslamcılıktaki Milliyetçilik”. Der. Y. Aktay, Modern Türkiye'de Siyasi Düşünce: İslamculık 6 (2014). İstanbul.

Duralı T. (2013, Nisan 8). “Ulus-Devletin Felsefi Değerlendirilmesi”. Bugün Gazetesi (2013, Nisan 8).

Ersoy M. A. (1993). Safahat. İstanbul 1993.

Gellner E. (2006). Uluslar ve Ulusçuluk. İstanbul 2006.

Günay Ü. (2000). Din Sosyolojisi. İstanbul (2000).

Güvenç B. (2006). Türk Kültürü ve Kimliği. İstanbul 2006.

Güvenç B. (2016). Türk Kimliği Kültür Tarihinin Kaynakları. İstanbul 2016.

Hobsbawm E. J. (2006). Milletler ve Milliyetçilik. İstanbul 2006.

Kabaklı A. (2006). Müslüman Türkiye. İstanbul 2006.

Kabaklı A. (2017). Türkiye'yi Yoğuranlar. İstanbul 2017.

Kara İ. (1987). Türkiye'de İslamcllk Düşüncesi: Metinler/Kişiler. İstanbul 1987.

Kahraman H. B. (1999). “Türkiye'de Kültürel Söylem Kurguları”. Doğu Batı Dergisi 9 (1999). Ankara.

Keyder Ç. ( 2003). Türkiye'de Devlet ve Siniflar. İstanbul 2003.

Koçak C. (2010). Geçmişiniz İtina ile Temizlenir. İstanbul 2010.

Lewis B. (2000). Modern Türkiye'nin Doğuşu. İstanbul 2000.

Mardin Ş. (2012). Türk Modernleşmesi Makaleler-4. İstanbul 2012.

Meriç C. (1993). Sosyoloji Notlart ve Konferanslar. İstanbul 1993.

Özel İ. (2009a). Tahrir Vazifeleri. İstanbul 2009. 
Özel İ. (2009b). Zor Zamanda Konuşmak. İstanbul 2009.

Özel İ. (2010a). Toparlanın Gitmiyoruz I. İstanbul 2010.

Özel İ. (2010b). Toparlanin Gitmiyoruz II. İstanbul 2010.

Özel İ. (2010c). Toparlanın Gitmiyoruz III. İstanbul 2010.

Özel İ. (2011a). Başbaş, Başbaşa, Başabaş. İstanbul 2011.

Özel İ. (2011b). Henry Sen Neden Buradasin II. İstanbul 2011.

Özel İ. (2012). Dedem Öldürürler, Demesem Öldüm. İstanbul 2012.

Özel İ. (2013). Küfrün İhsanı Olmaz. İstanbul 2013.

Özel İ. (2015). Türk Olmadlysan Oldun Amerikall. İstanbul 2015.

Rattansi A. \& Westwood S. (1997). Irkçllk, Modernite ve Kimlik. İstanbul 1997.

Said E. (1998). Oryantaliz. İstanbul 1998.

Smith A. D. (2010). Milli Kimlik. İstanbul 2010.

Topçu N. (2010). Mehmet Akif Ersoy, Bütün Eserleri 10. İstanbul 2010.

\section{Elektronik Kaynaklar}

“Mescid-i Dirar Meselesi”. (n.d.). İslam Ansiklopedisi 29 (n.d.), 272.

Kaynak: http://www.islamansiklopedisi.info/

Özel İ. (2007, Şubat 07). "Birinci Sene-i Devriye Merasimi".

Kaynak: http://www.istiklalmarsidernegi.org.tr/Yazi.aspx?YID=241\&KID=6

Özel İ. (2007, Haziran 09). "Kâfirden Kaçırılmış Metin: ‘İstiklal Marşı"”.

Kaynak: http://www.istiklalmarsidernegi.org.tr/Duyuru.aspx?DID=33

Özel İ. (2002, Kasım). Cuma Mektupları-6. Kaynak: http://www.istiklalmarsidernegi.org.tr/

Özel İ. (2008, Ağustos 16). "İstiklâl Marşı: Abide Milletin Kaidesi”.

Kaynak: http://www.istiklalmarsidernegi.org.tr/

Özel İ. (2009, Mayıs 19). “Türkiye Niçin Vatan?”. Kaynak: http://www.istiklalmarsidernegi.org.tr/

Özel İ. (2009, Aralık,05). "Milli Pazar Olmadan, Milli Birlik Olmaz".

Kaynak: http://www.istiklalmarsidernegi.org.tr/

Özel İ. (2010, Şubat 06). "Harç Bitti Yapıya Devam”. Kaynak: http://www.istiklalmarsidernegi.org.tr/

Özel İ. (2010, Kasım 10). "Uçbeyi? Uç Uç Böceği? Türksüz İslam Kimin Neyi”.

Kaynak: http://www.istiklalmarsidernegi.org.tr/

Özel İ. (2010, Nisan 10). "Hududu Aşmak, Hududu Korumak".

Kaynak: http://www.istiklalmarsidernegi.org.tr/

Özel İ. (2010, Mayıs 20). “Önce Millet Olduğumuzu Ortaya Koyalım”.

Kaynak: http://www.istiklalmarsidernegi.org.tr/

Özel İ. (2011, Ocak 29). "Ne Kaçaklara, Ne Oturaklılara Marş Gerektir".

Kaynak: http://www.istiklalmarsidernegi.org.tr/

Özel İ. (2011, Mart 12). "İstiklâl Marşı'nın Hayatımızdaki Yeri”.

Kaynak: http://www.istiklalmarsidernegi.org.tr/

Özel İ. (2012, Mart 17).“Bereketsiz İhanetler”. Kaynak: http://www.istiklalmarsidernegi.org.tr/

Özel İ. (2012, Mart 31). “Tapon Mallara Para Kaptıranın Anası Ağlasın”.

Kaynak: http://www.istiklalmarsidernegi.org.tr/ 